\title{
FAKTOR YANG BERHUBUNGAN DENGAN KUALITAS TIDUR MAHASISWA STIKES MANDALA WALUYA KENDARI
}

\author{
Factors Related to The Sleep Quality On Students In Mandala Waluya Science College \\ Kendari
}

\author{
Andi Mauliyana, Mohamad Guntur Nangi, Yordania Anamelania \\ Program Studi Sarjana Kesehatan Masyarakat \\ Universitas Mandala Waluya \\ (andimauliyana.kesmas@gmail.com, 085288839708)
}

\begin{abstract}
ABSTRAK
Kurangnya kebutuhan tidur akan berdampak pada menurunnya kemampuan untuk berkonsentrasi dalam aktivitas sehari-hari. Dari 12 orang mahasiswa angkatan 2016 hanya 3 orang yang memiliki jam tidur yang cukup, dan 9 orang mempunyai kebiasaan tidur di atas jam 12 malam. Penelitian ini bertujuan untuk mengetahui hubungan konsumsi kopi malam hari, aktivitas sampingan dan penggunaan handphone dengan kualitas tidur mahasiswa angkatan 2016 di STIKES Mandala Waluya Kendari. Jenis penelitian adalah analitik observasional dengan rancangan Cross Sectional. Populasi dalam penelitian ini adalah seluruh mahasiswa angkatan 2016 berjumlah 408 mahasiswa dengan jumlah sampel sebanyak 80 responden dengan teknik Proportional Random Sampling.Analisis menggunakan Uji Chi Square serta uji Koefisien Phi untuk melihat keberatan hubungan. Hasil uji Chi Square menunjukan bahwa ada hubungan antara konsumsi kopi malam hari dan penggunaan handphone dengan kualitas tidur mahasiswa angkatan 2016 di STIKES Mandala Waluya Kendari dengan nilai $\mathrm{X}^{2}$ hitung masing-masing 28,376 dan 7,370 serta nilai phi 0,596 dan 0,304 . Tidak ada hubungan antara aktivitas sampingan dengan kualitas tidur mahasiswa di STIKES Mandala Waluya Kendari dengan nilai $\mathrm{X}^{2}$ hitung 1,414 . Diharapkan pada peneliti selanjutnya dapat meneliti faktor-faktor yang berhubungan dengan kualitas tidur dengan menggunakan variabel lain seperti stress dan penyakit.
\end{abstract}

Kata Kunci : Kualitas tidur, konsumsi kopi, aktivitas sampingan

\begin{abstract}
Lack of need for sleep will have an impact on decreased ability to concentrate on daily activities. Of 12 students in the 2016 generation, only 3 students had adequate sleep hours, and 9 students had a habit of sleeping after midnight. This study was to determine the relationship between nighttime coffee consumption, side activities, and the use of handphones to the students' sleep quality in the 2016 generation at Mandala Waluya Health Science College Kendari. This study was observational analytic with a cross-sectional design. The population of this study was all students in generation 2016 amount of 408 students with a total sample of 80 respondents using the Proportional Random Sampling Technique. Data were analyzed using the Chi-Square Test as well as the phi coefficient test to see the objections to the relationship. The results of the Chi-Square Test show that there is a relationship between nighttime coffee consumption and the use of handphones with the student's sleep quality in 2016 generation at Mandala Waluya Health Science College Kendari with the value of $X^{2}$ count 28.376 and 7.370with a value of phi 0,596 and 0.304. There is no relationship between side activities and the student's sleep quality in the 2016 generation at Mandala Waluya Health Science College with the value of $X^{2}$ count 1.414. It is hoped that the next researchers can examine the factors related to sleep quality by using other variables such as stress and disease.
\end{abstract}

Keywords: Sleep quality, coffee consumption, side activities 


\section{PENDAHULUAN}

Hasil survei dari Royal Phillips mengungkapkan masyarakat dunia semakin kurang tidur. Enam puluh dua persen orang dewasa dalam survei global menggambarkan kualitas tidur mereka tidak sama sekali baik. Setengahnya $44 \%$ mengatakan bahwa tidur mereka telah memburuk dalam lima tahun terakhir. Sebuah data epidemiologi menjelaskan bahwa telah terjadi peningkatan angka keluhan pasien terhadap kualitas tidur. Hal tersebut didukung oleh hasil survei yang mengindikasikan bahwa $15-35 \%$ dari populasi remaja dan orang dewasa mengeluhkan gangguan kualitas tidur yang sering mereka alami, seperti gangguan memasuki tidur atau gangguan mempertahankan tidur sehingga durasi tidur menjadi pendek. Aspek tidur berkualitas masih sangat kurang, menurut data epidemiologi, Indonesia di perkirakan tiap tahun $20-40 \%$ prevalensi orang dewasa mengalami kesukaran tidur dan $17 \%$ diantaranya mengalami masalah serius. ${ }^{1}$

Sebuah penelitian mengidentifikasi $50 \%$ mahasiswa mengalami EDS dan $70 \%$ mahasiswa mengalami tidur yang tidak adekuat. Dampak dari kedua hal tesebut dapat mempengaruhi kemampuan belajar, gangguan pada mood dan kecelakaan kendaraan bermotor. Tidur yang tidak memadai dapat menyebabkan individu kurang bahagia, lebih tertekan, lemah secara fisik, dan merasa sangat lelah secara fisik dan mental. Selanjutnya, apabila dilakukan kajian lebih jauh, maka kualitas tidur yang buruk menjadi salah satu prediktor dari mortalitas. Hal tersebut di kemukakan dari beberapa peneliti yang menemukan bahwa 1902 dari 22.444 laki-laki dan 397 dari 10.902 perempuan meninggal akibat faktor-faktor yang berhubungan dengan gangguan tidur. ${ }^{2}$

Berbagai dampak yang dapat ditimbulkan oleh akibat kurangnya tidur pada setiap orang. Dari berbagai dampak yang ditimbulkan tersebut, aspek utama yang paling dipengaruhi oleh akibat kurangnya tidur pada seseorang yaitu aspek memori dan konsentrasi. Kondisi ini banyak dijumpai pada anak sekolahan, mahasiswa dan pekerja yang mempunyai jam kerja yang padat, dimana kelompok yang paling tinggi risikonya untuk terkena gangguan tidur yaitu mahasiswa. ${ }^{3}$

Berdasarkan studi pendahuluan yang dilakukan peneliti, pada 12 orang mahasiswa angkatan 2016 yang diwawancarai singkat mengenai tidurnya, hanya 3 orang yang memiliki jam tidur cukup, dan terdapat 9 orang sisanya mempunyai kebiasaan tidur di atas jam 12 malam. Dari hasil wawancararatarata mahasisa memiliki kebiasaan tidur larut malam ada berbagai ragam,tiga mahasiswa mengeluhkan bahwa mereka sulit tidur, mahasiswa tersebut mengatakan bahwa mereka mengkonsumsi kopi pada malam hari.

Selain aktivitas akademik, mahasiswa angkatan 2016 juga memiliki aktivitas sampingan yang dilakukan di luar perkuliahan akademik seperti organisasi intra juga organisasi ekstra. Meskipun mahasiswa mendapat wawasan tambahan seperti manajemen organisasi dan waktu. Namun pada kenyataannya, berdampak pada waktu istrahatnya. Beberapa mahasiswa mempunyai 
pekerjaan paruh waktu atau bahkan pekerjaan waktu penuh. Dampak dari kebiasaan tersebut jelas sekali akan menyebabkan mahasiswa sering mengantuk pada jam perkuliahan, menjadi mudah tersinggung, dan tidak dapat berkonsentrasi pada kuliah.

Kebiasaan 30 menit sebelum tidur yang memberikan stimulasi secara kognitif, psikologis, dan emosional di antaranya adalah membaca buku, mendengarkan musik, bermain game, menonton $\mathrm{tv}$, dan lain-lain. Kegiatan tersebut dapat menyebabkan seseorang menunda tidur sehingga terjadi gangguan pada pola tidur dan irama sirkardian. ${ }^{4}$ Pada aktifis organisasi, penurunan kualitas tidur menjadi persoalan yang relatif tinggi. Hal tersebut menjelaskan bahwa salah satu faktor yang menyebabkan terganggunya tidur mahasiswa adalah aktifitas non akademik. $^{5}$

Penggunaan handphone telah lama dikaitkan dengan potensi kebiasaan yang meresahkan dan membahayakan, hal ini meningkatkan kewaspadaan tentang efek samping penggunaan handphone berlebihan terhadap kesehatan fisik dan mental mahasiswa. Penggunaan handphone malam hari pada mahasiswa juga berpengaruh terhadap kualitas tidurnya. Penggunaan handphoneatau telpon genggam dapat menjadikan seseorang mengalami sulit tidur. Hal initerkait dengan kenikmatan saat menggunakan alat teknologi seperti smartphone yang dapat membuat si pengguna sibuk dengan sendirinya hingga lupa waktu.

Berdasarkan permasalahan diatas, penulis tertarik melakukan penelitian dengan mengangkat judul faktor-faktor yang berhubungan dengan kualitas tidur pada mahasiswa di STIKES Mandala Waluya Kendari.

\section{BAHAN DAN METODE}

Jenis penelitian ini adalah penelitian analitik observasional dengan rancangan Cross Sectional. Cross sectional adalah penelitian non eksperimental untuk mempelajari dinamika korelasi antarafaktor-faktor risiko denganefek, dengan cara pendekatan, observasi atau pengumpulan data sekaligus pada suatu saat (Point time approach). ${ }^{6}$ Populasi dalam penelitian ini adalah seluruh mahasiswa angkatan 2016 yang aktif atau ikut perkuliahan secara aktif di STIKES Mandala Waluya Kendari berjumlah 408 mahasiswa. Jumlah sampel yang diambil dalam penelitian ini 80 responden. Pemilihan sampel dalam penelitian ini ditentukan dengan cara Proportional Random Sampling berdasarkan program studi. Analisis statistik dilakukan dengan menggunakan uji Chi Square serta menggunakan uji Koefisien Phi untuk melihat keeratan hubungan.

\section{HASIL}

Tabel 1 menunjukkan bahwa dari 80 responden penelitian yang di teliti, terbanyak adalah kelompok umur 22-28 tahun yaitu sebanyak 71 responden $(88,8 \%)$ dan yang terkecil adalah umur 36-42 dan 43-49 tahun masing-masing sebanyak 2 responden (2,5\%). Dari 80 responden penelitian yang di teliti, terbanyak adalah berjenis kelamin laki-laki yaitu sebanyak 54 responden $(67,5 \%)$ dan 
paling sedikit adalah berjenis kelamin perempuan sebanyak 26 responden $(32,5 \%)$. Dari 80 responden penelitian yang diteliti, terbanyak adalah Program Studi Farmasi yaitu sebanyak 28 responden $(35,0 \%)$ dan paling sedikit adalah Program Studi Teknik Elektromedik yaitu sebanyak 5 responden $(6,2 \%)$.

\section{Tabel 1. Karakteristik Responden}

\begin{tabular}{lcc}
\hline \multicolumn{1}{c}{$\begin{array}{c}\text { Karakteristik } \\
\text { Responden }\end{array}$} & n (80) & \% \\
\hline Kelompok Umur & & \\
22-28 tahun & 71 & 88,8 \\
29-35 tahun & 5 & 6,2 \\
36-42 tahun & 2 & 2,5 \\
43-49 tahun & 2 & 2,5 \\
\hline Jenis Kelamin & & \\
Laki-laki & 54 & 67,5 \\
Perempuan & 26 & 32,5 \\
\hline Program Studi & & \\
Farmasi & 28 & 35,0 \\
Teknik Elektromedik & 5 & 6,2 \\
Teknik Laboratorium & 9 & 11,2 \\
Medik & 26 & 32,4 \\
Keperawatan & 12 & 15,0 \\
Kesehatan Masyarakat & 12 & \\
\hline Sumber : Data primer, 2020 & &
\end{tabular}

Tabel 2. Analisis Univariat

\begin{tabular}{lcc}
\hline \multicolumn{1}{c}{ Variabel } & n $(\mathbf{8 0})$ & $\%$ \\
\hline $\begin{array}{l}\text { Konsumsi kopi malam } \\
\text { hari }\end{array}$ & & \\
Ya & 53 & 66,2 \\
Tidak & 27 & 33,8 \\
\hline Aktivitas sampingan & & \\
Ya & 39 & 48,8 \\
Tidak & 41 & 51,2 \\
\hline Penggunaan handphone & & \\
Ya & 72 & 90,0 \\
Tidak & 8 & 10,0 \\
\hline Kualitas tidur & & \\
Baik & 19 & 23,8 \\
Buruk & 61 & 76,2 \\
\hline Sumber $:$ Data primer, 2020 & &
\end{tabular}

Sumber : Data primer, 2020

Tabel 2 menunjukkan bahwa dari 80 responden, terdapat 53 responden $(66,2 \%)$ yang mengonsumsi kopi di malam hari dan terdapat 27 responden $(33,8 \%)$ yang tidak mengkonsumsi kopi di malam hari. Dari 80 responden, terdapat 39 responden $(48,8 \%)$ yang melakukan aktivitas sampingan dan terdapat 41 responden $(51,2 \%)$ yang tidak melakukan aktivitas sampingan.dari 80 responden, terdapat 72 responden $(90,0 \%)$ yang menggunakan hanphone sebelum tidur malam dan terdapat 8 responden $(10,0 \%)$ yang tidak menggunakan handphone sebelum tidur malam. Dari 80 responden, terdapat 19 responden $(23,8 \%)$ yang mempunyai kualitas tidur baik dan terdapat 61 responden $(76,2 \%)$ yang mempunyai kualitas tidur buruk.

Tabel 3 menunjukkan bahwa dari total 80 responden, terdapat 53 responden yang tidak mengkonsusmsi kopi malam hari, dan 61 responden $(76,2 \%)$ yang memiliki kualitas tidur buruk. Dari 53 responden yang tidak mengkonsusmsi kopi malam hari terdapat 50 responden $(94,3 \%)$ yang memiliki kualitas tidur buruk dan 3 reponden $(5,7 \%)$ memiliki kualitas tidur baik. Sedangkan dari 27 responden yangmengkonsusmsi kopi malam hari terdapat 11 responden $(40,7 \%)$ yang memiliki kualitas tidur buruk dan 16 responden $(59,3 \%)$ memiliki kualitas tidur baik.Berdasarkan hasil analisis data dengan menggunakan uji statistic Chi Square diketahui $\mathrm{X}^{2}$ tabel=3,841 pada taraf kepercayaan $95 \%$ diperoleh hasil $\mathrm{X}^{2}$ hitung $>X^{2}$ tabel yaitu 28,376 maka H0 ditolak dan Ha diterima. Hal ini menunjukkan bahwa ada hubungan antara konsumsi kopi malam hari dengan kualitas tidur mahasiswa angkatan 2016 di STIKES Mandala Waluya Kendari. 
Tabel 3. Analisis Bivariat

\begin{tabular}{|c|c|c|c|c|c|c|c|}
\hline \multirow{3}{*}{ Variabel } & \multicolumn{6}{|c|}{ Kualitas Tidur } & \multirow{3}{*}{ Uji Statistik } \\
\hline & \multicolumn{2}{|c|}{ Buruk } & \multicolumn{2}{|c|}{ Baik } & \multicolumn{2}{|c|}{ Jumlah } & \\
\hline & $\mathrm{n}$ & $\%$ & $\mathrm{n}$ & $\%$ & $\mathrm{n}$ & $\%$ & \\
\hline Konsumsi kopi malam hari & & & & & & & $X^{2}$ hit $=28,376$ \\
\hline Tidak & 50 & 94,3 & 3 & 5,7 & 53 & 100 & $X^{2} \operatorname{tab}=3,841$ \\
\hline Ya & 11 & 40,7 & 16 & 59,3 & 27 & 100 & Phi $=0,596$ \\
\hline Aktivitas sampingan & & & & & & & \\
\hline Tidak & 29 & 70,7 & 12 & 29,3 & 41 & 100 & $X^{2}$ hit $=1,414$ \\
\hline Ya & 32 & 82,1 & 7 & 17,9 & 38 & 100 & $\mathrm{X}^{2} \mathrm{tab}=3,841$ \\
\hline Penggunaan handphone & & & & & & & $\mathrm{X}^{2}$ hit $=7,370$ \\
\hline Tidak & 3 & 37,5 & 5 & 62,5 & 8 & 100 & $\mathrm{X}^{2} \mathrm{tab}=3,841$ \\
\hline Ya & 58 & 80,6 & 14 & 19,4 & 72 & 100 & Phi $=0,304$ \\
\hline
\end{tabular}

Sumber : Data primer, 2020

Dengan nilai phi 0,596 yang berarti ada hubungan kuat antara konsumsi kopi malam hari dengan kualitas tidur mahasiswa angkatan 2016 di STIKES Mandala Waluya Kendari.

Dari total 80 responden, terdapat 41 responden yang tidak aktif mengikuti organisasi dan atau olahraga, dan 61 responden $(76,2 \%)$ yang memiliki kualitas tidur buruk.Dari 41 responden yang tidak melakukan aktivitas sampingan terdapat 29 responden $(70,7 \%)$ yang memiliki kualitas tidur buruk dan 12 reponden (29,3\%) memiliki kualitas tidur baik. Sedangkan dari 38 responden yangmelakukan aktivitas sampingan terdapat 32 responden $(82,1 \%)$ yang memiliki kualitas tidur buruk dan 7 responden $(17,9 \%)$ memiliki kualitas tidur baik. Berdasarkan hasil analisis data dengan menggunakan uji statistic Chi Square diketahui $\mathrm{X}^{2}$ tabel=3,841 pada taraf kepercayaan $95 \%$ diperoleh hasil $X^{2}$ hitung $<\mathrm{X}^{2}$ tabel yaitu 0,834 maka $\mathrm{H} 0$ diterima dan Ha ditolak. Hal ini menunjukkan bahwa tidak ada hubungan antara aktivitas sampingan dengan kualitas tidur mahasiswa angkatan 2016 di STIKES Mandala Waluya Kendari.

Dari total 80 responden, terdapat 72 responden yang menggunakan handphone sebelum tidur malam, dan 61 responden $(76,2 \%)$ yang memiliki kualitas tidur buruk. Dari 8 responden yang tidak menggunakan handphone sebelum tidur malam terdapat 3 responden $(37,5 \%)$ yang memiliki kualitas tidur buruk dan 5 reponden $(62,5 \%)$ memiliki kualitas tidur baik. Sedangkan dari 72 responden yangmelakukan aktivitas sampingan terdapat 58 responden $(80,6 \%)$ yang memiliki kualitas tidur buruk dan 14 responden $(19,4 \%)$ memiliki kualitas tidur baik. Berdasarkan hasil analisis data dengan menggunakan uji statistic Chi Square diketahui $\mathrm{X}^{2}$ tabel=3,841 pada taraf kepercayaan 95\% diperoleh hasil $X^{2}$ hitung > $\mathrm{X}^{2}$ tabel yaitu 7,370 maka H0 ditolak dan Ha diterima. Hal ini menunjukkan bahwa ada hubungan antara penggunaan handphone sebelum tidur malam dengan kualitas tidur mahasiswa angkatan 2016 di STIKES 
Mandala Waluya Kendari.Dengan nilai phi 0,304 yang berarti ada hubungan sedang antara penggunaan handphone dengan kualitas tidur mahasiswa angkatan 2016 di STIKES Mandala Waluya Kendari.

\section{PEMBAHASAN}

Kopi merupakan jenis minuman berkafein yang paling sering dikonsumsi. Kafein bekerja dengan cara berikatan sementara pada reseptor adenosin mencegah ikatan adenosin (zat sedatif alami yang membuat rasa kantuk) dengan reseptornya di otak. $^{7}$ Di antara 53 responden yang mengonsumsi kopi malam hari terdapat 3 responden $(5,7 \%)$ yang memiliki kualitas tidur baik, hal ini dikarenakan waktu konsumsi kopi responden mengatakan bahwa mereka minum kopi bukan pada malam hari melainkan pada pagi hari juga siang hari. Dan 50 responden $(94,3 \%)$ lainnya yang mengonsumsi kopi malam hari dan memiliki kualitas tidur buruk disebabkan karena efek kafein terhadap tidur. Efek kafein dalam kopi bekerja dalam mencegah ikatan adenosin, adenosin merupakan sebuah senyawa dalam tubuh yang membuat seseorang mengantuk, kafein menghambat kerja adenosin reseptor dalam tubuh sehingga membuat seseorang terhindar dari rasa kantuk. Hal ini menunda jam tidur sehingga kualitas tidur mahasiswa terganggu.

Mengkonsumsi kafein sebelum tidur dapat menurunkan atau mengganggu waktu tidur, meningkatkan jam tidur dan bangun tidur lebih awal. Kafein dihubungkan dengan penurunan frekuensi dari gelombang alpha, beta dan theta selama tidur.Alasan yang mungkin untuk efek kafein pada tidur berasal dari peran adenosin. Adenosin neurotransmiter yang efeknya mengurangi aktifitas sel terutama sel saraf. ${ }^{8}$ Hasil uji keeratan hubungan didapatkan nilai phi 0,596 yang berarti konsumsi kopi malam hari memiliki kontribusi sebesar 59,6\% terhadap kualitas tidur mahasiswa angkatan 2016 di STIKES Mandala Waluya Kendari.Hal ini sejalan dengan penelitian Rabi'ahtul Adawiyah di Fakultas Kedokteran Universitas Sumatera Utara menunjukkan hasil bahwa terdapat efek konsumsi kopi terhadap kualitas tidur dengan hasil uji Chi Square di dapatkan nilai $p$-value $(\mathrm{p}<0,014)$.

Banyak mahasiswa yang menjadikan kopi sebagai teman belajar karena kebanyakan mereka berharap setelah minum kopi akan tetap terjaga dan menyelesaikan materi ujian ataupun tugas untuk esok hari. Selain itu kopi zaman sekarang banyakbermunculan varian rasa yang beragam. Orang yang biasanya tidak begitu tertarik dengan rasa kopi hitam dapat merasakan kopi yang dicampur dengan susu atau varian yang lain.

Aktivitas sampingan merupakan suatu kegiatan atau pekerjaan lain sebagai selingan atau tambahan selain pekerjaan pokok atau kegiatan pokok. Aktivitas sampingan yang dilakukan mahasiswa yakni aktivitas diluar perkuliahan atau aktifitas non akademik yaitu ekstrakurikuler seperti mengikuti organisasi kemahasiswaan dan olahraga.

Dari total 39 responden yang melakukan aktivitas sampingan, ada 28 responden $(71,8 \%)$ yang memiliki kualitas tidur buruk dan 11 responden $(28,2 \%)$ yang memiliki 
kualitas tidur baik. Hal ini disebabkan karena sebagian besar responden mengatakan bahwa mereka sukamenunda jadwal atau waktu tidur maka kualitas tidur yang dimiliki mahasiswa menjadi buruk. Adapun responden yang melakukan aktivitas sampingan tetapi memiliki kualitas tidur yang baik. Pada saat wawancara responden mengatakan bahwa mereka melakukan aktivitas lain seperti mendengarkan musik sebelum tidur sehingga mereka mudah tertidur, hal tersebut membuat kualitas tidur responden di malam hari tidak terganggu.

Kemudian dari total 41 responden yang tidak melakukan aktivitas sampingan, ada 33 responden $(80,5 \%)$ yang memiliki kualitas tidur buruk dan 8 responden (19,5\%) yang memiliki kualitas tidur baik. Responden juga mengatakan bahwa pada malam hari mereka mudah teridur tergantung cahaya pada saat mereka tidur, kebanyakan dari mereka dapat tidur dengan mudah apabila lampu di padamkan. Hasil penelitian ini menunjukkan bahwa tidak ada hubungan antara aktivitas sampingan dengan kualitas tidur mahasiswa angkatan 2016 di STIKES Mandala Waluya Kendari.Hal ini sejalan dengan penelitian lain yaitu tidak ada hubungan antara aktivitas fisik atau aktivitas sampingan dengan kualitas tidurpada remaja di SMA Negeri 1 Ungaran $(\mathrm{p}=0,927){ }^{9}$

\section{Handphone adalah perangkat} telekomunikasi elektronik yang mempunyai kemampuan dasar yang sama dengan telepon konvensional saluran tetap, tetapi dapat dibawa kemana-mana dan tidak perlu disambungkan dengan jaringan telepon menggunakan kabel. Tren menggunakan handphone di Indonesia semakin marak. Menurut Kim, masyarakat Indonesia sangat responsif dan mengutakan handphone dalam beragam aktivitas wisata, dari mulai mencari informasi sampai mengupdate atau mempublikasikan wisatanya melalui media sosial.

Dari total 72 responden yang menggunakan handphone sebelum tidur malam, ada 14 responden $(19,4 \%)$ yang memiliki kualitas tidur baik dan 58 responden $(80,6 \%)$ yang memiliki kualitas tidur buruk. Responden yang memiliki kualitas tidur yang baik meskipun menggunakan handphone sebelum tidur malam. Pada saat wawancara responden mengatakan bahwa mereka tidur dengan mudah karena durasi penggunaan handphone tidak terlalu lama, sehingga responden tidur lebih awal dibandingkan responden yang memiliki kualitas tidur buruk.

Pemakaian media elektronik yang patologis sebelum tidur apabila digunakan lebih dari 35 menit. Sedangkan untuk reponden yang menggunakan handphone sebelum tidur malam dan memiliki kualitas tidur buruk disebabkan karena menggunakan handphone dengan durasi yang sangat lama. Satu dari sepuluh remaja tidak mendapat tidur yang cukup di malam hari akibat penggunaan handphone dan komputer yang membuat mereka menunda jam tidur dan membangunkan mereka di tengah tidur sehingga membutuhkan waktu yang lebih lama untuk tidur kembali. ${ }^{10}$

Hasil uji keeratan hubungan didapatkan nilai phi 0,304 yang berarti penggunaan 
handphone sebelum tidur malammemiliki kontribusi sebesar $30,4 \%$ terhadap kualitas tidur mahasiswa angkatan 2016 di STIKES Mandala Waluya Kendari. Hal ini sejalan dengan penelitian lain yang menyatakan bahwa ada hubungan penggunaan gadget dan durasi penggunaan gadget dengan kualitas tidur pada remaja.

Secara fisiologi tubuh tidur diatur di pusat otak dibagian RAS (Reticular Activating System) dan BSR (Bulbar Synchronizing System). BSR akan aktif saat kondisi lingkungan yang tenang dan nyaman sehingga seseorang akan tidur, namun pada saat mahasiswa menggunakan gadget maka otak akan menerima stimulus dari luar yang berupa suara, cahaya dan getaran dari gadget, selanjutnya otak mengirimkan sinyal tersebut yang dapat mengaktifkan RAS sehingga menyebabkan remaja tetap terjaga di malam hari. Jika hal ini berlangsung dalam waktu yang lama maka akan dapat mengganggu kualitas tidur. $^{11}$

\section{KESIMPULAN DAN SARAN}

Kesimpilan dari penelitian ini yaitu ada hubungan kuat antara konsumsi kopi malam hari dengan kualitas tidur pada mahasiswa di STIKES Mandala Waluya Kendari Tahun 2020, tidak ada hubungan antara aktivitas sampingan dengan kualitas tidur pada mahasiswa di STIKES Mandala Waluya Kendari Tahun 2020. Ada hubungan sedang antara penggunaan handphone dengan kualitas tidur pada mahasiswa di STIKES Mandala WaluyaKendari Tahun 2020.
Hasil penelitian ini diharapkan dapat dijadikan sebagai bahan masukan kampus khususnya mahasiswa dalam menambah ilmu terkait faktor-faktor yang berhubungan dengan kualitas tidur. Hasil penelitian ini diharapkan mahasiswa dapat mengurangi konsumsi kopi malam hari, kurangi aktivitas yang berlebihan serta kurangi penggunaan handphone sebelum tidur malam, karena hal tersebut dapat menimbulkan gangguan tidur yang akan mengakibatkan penurunan kualitas tidur.Dari hasil penelitian ini diharapkan peneliti dapat meneliti tentang faktor-faktor yang berhubungan dengan kualitas tidur dengan variabel lain seperti stress dan penyakit.

\section{DAFTAR PUSTAKA}

1. Wulandari RP. Hubungan Tingkat Stress Dengan Gangguan Tidur Pada Mahasiswa Skripsi Di Salah Satu Fakultas Rumpun Science-Tecnology UI. Karya Tulis Ilmiah, Fakultas Ilmu Keperawatan Universitas Indonesia. Jakarta; 2019.

2. Fenny, Supriatmo. Hubungan Kualitas dan Kuantitas Tidur Dengan Prestasi Belajar Pada Mahasiswa Fakultas Kedokteran. Skripsi. Fakultas Kedokteran Sumatera Utara. 2016.

3. Nashori F, Wulandari ED. Psikologi Tidur: Kualitas Tidur Hingga Insomnia. Skripsi. Universitas Islam Indonesia. Yogyakarta; 2017.

4. Amalina, Shyrien. Hubungan Penggunaan Media Elektronik dan Gangguan Tidur. Ilmu Kesehatan Anak Fakultas Kedokteran Universitas Gadjah Mada. Jurnal Sari Pediatri.2015;17(4):273-278. 
5. Gaultney J. The Prevalence Of Sleep Disorders In College Students: Impact On Academic Performance. Journal Of American College Health. 2010;59(2):9197.

6. Notoadmojo S.Metodologi Penelitian Kesehatan. PT Aneka Citra. Jakarta; 2010.

7. Youngberg et al. Clinical and physiological correlates of caffeine and caffeine metabolites in primary insomnia. Journal of Clinical Sleep Medicine. 2011;7(2):196-203.

8. Huang Z L, Qu, WM, Eguchi N, Chen JF, Schwarzschild MA, Fredholm BB, Urade Y, Hayaishi O. Adenosine A2A, But Not A1, Receptors Mediate The Arousal Effect Of Caffeine. Nature Neuroscience. 2005;8(7):858-859.

9. Yolanda. Hubungan Aktivitas Fisik, Screen Based Activity dan Sleep Hygien Dengan Kualitas Tidur Pada Remaja Usia 15-18 Tahun. Jurnal Kesehatan Masyarakat. 2019;7(1):2356-3346.

10. King DL, Delfabbro PH, Zwaans T, Kaptsis D. Sleep Interference Effects of Pathological Electronic Media Use During Adolescence. International Journal of Mental Health and Addiction. 2014;12(1):21-35.
11. Jarmi, Armaya. Hubungan Penggunaan Gadget Dengan Kualitas Tidur Remaja Di SMP Negeri 1 Banda Aceh. Skripsi. Universitas Unsiyah Kuala. Banda Aceh; 2017. 